\title{
Correction to: Prevalence of posttraumatic arthritis and the association with outcome measures following distal radius fractures in non-osteoporotic patients: a systematic review
}

\author{
C. M. Lameijer ${ }^{1}$ H. J. ten Duis ${ }^{1} \cdot$ I. van Dusseldorp ${ }^{2}$ P. U. Dijkstra ${ }^{3,4}$. C. K. van der Sluis ${ }^{3}$
}

Published online: 14 September 2021

(c) The Author(s) 2021

\section{Correction to: \\ Arch Orthop Trauma Surg (2017) 137:1499-1513 \\ https://doi.org/10.1007/s00402-017-2765-0}

Unfortunately, the given name and family name of the third author was incorrectly tagged in the xml data, therefore it is abbreviated wrongly as "Dusseldorp IV" in PubMed. The correct given name is Ingeborg and family name is van Dusseldorp.

Open Access This article is licensed under a Creative Commons Attribution 4.0 International License, which permits use, sharing, adaptation, distribution and reproduction in any medium or format, as long as you give appropriate credit to the original author(s) and the source, provide a link to the Creative Commons licence, and indicate if changes were made. The images or other third party material in this article are included in the article's Creative Commons licence, unless indicated otherwise in a credit line to the material. If material is not included in the article's Creative Commons licence and your intended use is not permitted by statutory regulation or exceeds the permitted use, you will need to obtain permission directly from the copyright holder. To view a copy of this licence, visit http://creativecommons.org/licenses/by/4.0/.

Publisher's Note Springer Nature remains neutral with regard to jurisdictional claims in published maps and institutional affiliations.

The original article can be found online at https://doi.org/10.1007/ s00402-017-2765-0.

C. M. Lameijer

C.M.Lameijer@UMCG.nl

1 Department of Trauma Surgery, University Medical Center Groningen, University of Groningen, 30.001, Huispostcode BA51, 9700 RB Groningen, The Netherlands

2 Medical Center Leeuwarden, MCL Academy, Leeuwarden, The Netherlands

3 Department of Rehabilitation Medicine, University Medical Center Groningen, University of Groningen, Groningen, The Netherlands

4 Department of Oral and Maxillofacial Surgery, University Medical Center Groningen, University of Groningen,

Groningen, The Netherlands 